\title{
Missing Books in the Folk Codicology of Later Medieval England
}

Such a collection Dennistoun had hardly dreamed of in his wildest moments. Here were ten leaves from a copy of Genesis, illustrated with pictures, which could not be later than A.D. 700. Further on was a complete set of pictures from a Psalter, of English execution, of the very finest kind that the thirteenth century could produce; and, perhaps best of all, there were twenty leaves of uncial writing in Latin, which, as a few words seen here and there told him at once, must belong to some very early unknown patristic treatise.

In M. R. James’s ghost story 'Canon Alberic’s Scrap-Book', an antiquarian encounters a haunted collection of manuscript fragments. ${ }^{1}$ The metaphor offered by this story for the study of surviving manuscripts, an activity which might be understood as the raising of ghosts, has been noted by John Scattergood in a brief, perceptive reading. ${ }^{2}$ But 'Canon Alberic’s ScrapBook’ points more particularly to the problem posed by missing manuscripts. The scrap-book or album paradoxically preserves exciting material while also reminding its readers of a larger body of lost evidence: all the manuscripts from which the scraps were taken. ${ }^{3}$ Such scrap-books are frustrating evidence. Complete medieval manuscripts are more comforting, and they survive in comfortingly large numbers, relative to individual scholars' research time: for example, there are around ten thousand Western examples in the Bodleian Library, or enough for forty years of study with a new manuscript every working day. These numbers are, however, tiny relative to the numbers which are lost: it is estimated that ninety-five to ninety-eight percent of all the medieval manuscripts once produced have disappeared. ${ }^{4}$ Furthermore, the manuscripts which remain constitute a patchy collection of unusual survivors, preserved for reasons which are hardly neutral, such as size, beauty or a particular provenance. Canon Alberic’s fragmentary and haunted scrap-book is, then, a fine synecdoche 
for the surviving manuscript record. The most spectral medieval manuscripts are all those which no longer exist, and the simple fact that a few other books survive skews scholarship. A total rebalancing is impossible, but I believe and will demonstrate here that it is possible to study the lost manuscripts of later medieval England productively. ${ }^{5}$ What might we learn if we let later medieval England's missing books haunt us? The process will unearth new codicological facts, which are surveyed in the opening part of this study. It will also offer new insights into later medieval attitudes towards the physical book. Studying missing books entails studying traces left by readers’ experiences of looking at, handling and recalling nowlost reading material. Later medieval readers sometimes displayed a historical sensitivity to manuscripts’ age, or deployed the idea of beauty while sorting books—not within an explicit structure of aesthetic thought, but as a practical, instrumental aid. I will also argue, however, that later medieval readers and owners sometimes found writing's physicality to be a hindrance, and could actively avoid thinking about the material book. Readers might be intimately aware of manuscripts’ unique foibles, or they might idealize the book in a flight from those same qualities. Work in manuscript studies could, I suggest, do more to account for readers and writers who were not interested in the physical book or were inconvenienced by books’ physicality, alongside those readers who were enthused or fascinated by books.

While the vast majority of medieval manuscripts may be absent, descriptions of some lost books do survive in wills, catalogues and inventories. These sources have been well studied to answer important questions in intellectual and cultural history: to learn who read what, where. However, there has been little systematic study of the physical details contained in these descriptions, and of the attitudes towards books which they suggest. In noting any physical details at all about books, recorders were practising what I call 'folk codicology'. By 'folk codicology' I mean descriptions of physical aspects of codices by people lacking modern scholarship’s diachronic and synchronic breadth of knowledge. This is, then, not a 
suggestion that those who compiled wills and book lists were ignorant: many such writers were thoroughly integrated into documentary culture and worked semi-professionally or professionally as scribes. They knew more about medieval books than we do, just as any speaker of any of the vernaculars of medieval Britain intuitively knew their language better than any modern scholar can, even after decades of study. However, a modern historical linguist does have a far more organized, articulated and programmatic grasp of, for example, morphology and grammar-indeed, in those matters certain advantages accrue from seeing the language 'from outside’. And, likewise, today’s professional codicologist has certain advantages over the fourteenth-century professional scribe. Even accepting that copying books might be, in Ralph Hanna’s words, ‘something of a fanatic’s occupation,' no later medieval scribe could take several texts and spend years comparing more than a hundred different manuscript copies of each one, as a modern codicologist might, and very few scribes would have had the chance to read thousands upon thousands of book records. ${ }^{6}$ So in proposing the phrase 'folk codicology' I am not denigrating the knowledge of medieval professionals, but rather recognising that in some ways we will never match that knowledge. Modern scholars might, therefore, want to draw upon its results.

These descriptions are after all the first codicological notices of the manuscripts they mention, and in most cases also the only ones. Later medieval readers were perfectly capable of thinking about books and the processes of reading: Daniel Wakelin has shown, for example, that readers such as William Worcester could historicize their own reading of the books they handled. ${ }^{7}$ Granted, Worcester was idiosyncratic. The physical details in a typical medieval book description are usually more fleeting than his careful observations: a representative example from the 1387 inventory of the books of Simon de Burley describes a book of Arthurian romance with a 'covere de blanc' (cover of white) ${ }^{8}$ Little can be done with just one such glimpse of just one physical feature. These small details can, however, be 
collected and surveyed, and once gathered together they are open to the codicologicallyinformed analysis of proportions and groups: data which are singly gnomic can become multiply revealing. Furthermore, unlike Worcester's atypical observations, briefer and more practical descriptions can reveal more widespread behaviours. Granted, practical book descriptions are not, in some naive way, more reliable texts than Worcester's writings. The evidential issues thrown up by wills are well-established. On the one hand, the language of wills could be formulaic, and could be the work of testators, or the work of scribes and notaries, or a complex mixture. ${ }^{9}$ On the other hand, and simultaneously, the habits and favoured formulas of those who wrote wills for testators could vary, simply from individual to individual and across different regions and jurisdictions. ${ }^{10}$ Furthermore, wills could focus on especially notable possessions, or on loose ends in situations which might otherwise be left to trusted executors, rather than attempting a complete account of a person's possessions. ${ }^{11}$ Medieval wills are far from being uniform documents, interchangable one with another. Problems in research using non-testamentary book lists have received less published discussion, but these lists too were written for pragmatic purposes—such as valuing a collection or locating different parts of it—not to help future scholars. The information about missing books offered by this evidence is not complete, consistent or somehow objective. Nevertheless, it includes glimpses of books about which we would otherwise know nothing. These glimpses are short, practical and descriptive phrases, and I will not conduct here the type of rhetorical analysis of extended quotations which would assume that different documents were wholly comparable. And, moreoever, the fact of the variability of wills and inventories strengthens the value and evidential force of any commonalities which can be identified in examples created by a large population of recorders, across an extended period of time. 


\section{Raising dead books}

As an initial exercise, I have read Susan H. Cavanaugh's survey of books mentioned in around eight thousand documents, $c .1300$ to $c .1450$, and collected every description which specifies any physical details. ${ }^{12}$ The documents concerned are mostly wills and inventories left by private owners, and so this sample focuses on individuals' books, but a few physical descriptions come from library catalogues which record donations from individuals. The resulting list records 1217 separate instances of a person in later medieval England choosing to describe at least one physical aspect of a manuscript. I have done my best to exclude descriptions of manuscripts which have been securely identified with a surviving book; the thought that, to my knowledge, none of these books exists today is itself sobering. I have counted various features across the full set of descriptions, and I have also examined particularly interesting examples in detail. To balance this heterogeneous collection of descriptions from Cavanaugh’s work, I have also read widely in institutional library catalogues, and gathered every physical description of a now-lost book I could find in one example: the catalogue of St Augustine’s Abbey, Canterbury, in which I found 294 such descriptions. ${ }^{13}$

Despite the use of 1511 separate quotations, however, this is not an exercise in the use of 'Big Data', nor in the 'distant reading' proposed by Franco Moretti, interesting as these approaches are. I use a significantly smaller corpus than, for example, 7,000 novel titles, and Pierre Gasnault’s older single-inventory study of the Papal Library at Avignon has been a more important model. ${ }^{14}$ Personally reading, categorizing and counting every folkcodicological description found seemed to be the best way to grasp the material. The numbers which appear in my argument might suggest precision, but they should be treated with just as much caution as any other evidence; they are aids in the study of trends and attitudes, rather than exact statistics. ${ }^{15}$ Some other qualifications should also be addressed here. A certain 
amount of error is to be expected in the print sources gathered by Cavanaugh, as these are often the products of older scholarship. They sometimes have their own transmission history, from one printed compendium to another, risking transcription errors at every stage. Fortunately this study does not require complete precision: broad trends in the evidence can be revealing without every spelling and date being exactly accurate. A more significant problem is posed by these sources' own selectivity. As noted above, neither type of document had to be comprehensive in its listing. Indeed, in some respects such lists just reproduce the prejudices of the physically surviving corpus: books which were likely to be described in inventories and wills most often contained Latin texts and tended to be valuable. ${ }^{16}$ Then, in turn, eighteenth- and nineteenth-century scholarship on these records sometimes imposed its own priorities: for example, one of the many compilations underlying this study defined its range as the wills of royalty and of those with royal ancestors. ${ }^{17}$ So, in another contrast to distant reading, this evidence does not permit totalization: it extends the limited view afforded by the surviving books, but it remains a very partial sample, not the hotline to 'all of literary history’ that might perhaps be accessed using the more complete records of later periods. ${ }^{18}$ However, explicitly recognizing the significant differences between the interests of modern scholarship and the preservation priorities of several other points in time is a valuable process in itself. It is useful to be reminded, for instance, that English was not a significant feature in most of the books which were felt to be worth recording. Furthermore, so long as the evidence exists, these qualifications caution against misusing it, not against using it at all. The records have weaknesses and biases, but the evidence they offer should still be used, not left on the shelf. 


\section{Codicological facts}

Some information about missing books can be gleaned from the patterns of codicological facts which surviving descriptions reveal. Even basic information of this sort still offers us traces of medieval experience. For example, medieval descriptions can enhance our understanding of books’ appearances. Because post-medieval rebinding has destroyed the majority of bindings from the period, and because time has sapped, dirtied or smudged the colour of those bindings which do survive, more evidence for the visual impression given by medieval books is always useful. ${ }^{19}$ Among the records I have collected from Cavanaugh, 268 descriptions specify books' exterior colours. ${ }^{20}$ Red (104 descriptions) is the dominant colour, and its only close competitor is white (83 descriptions); together, red books and white books make up almost three quarters of those whose colour is mentioned. These figures certainly do not mean that forty percent of the books in later medieval England had red bindings while thirty percent had white bindings, but they offer firmer ground for saying that common kinds of covering were reddened or alum-tawed leather. ${ }^{21}$ Black is the third most common colour mentioned, but it appears far less frequently (26 descriptions) and only a few times more than green (21). Gasnault's study of the papal collection at Avignon found a very different colourscape: first green (570), then red (400), white (267) and black (71). ${ }^{22}$ Perhaps this difference is the result of regional variation, or collection-specific idiosyncrasies: one individual collection is much more sensitive to individual whims over time than the aggregate of many individuals’ collections. That leather was the most common material for covering seems almost certain, as words meaning leather or skin (corium, cuir) are used in roughly two thirds (127) of the 185 descriptions that specify any binding material, while the next most common coverings, cloth and velvet, appear a mere twenty and eighteen times respectively.

Other materials specified only a few times are baudekin (5 descriptions), silk (5) and worsted (2); damask, samite, taffeta and satin all appear once only. Parchment is also specified once 
as a covering, which in this specific case probably indicates the use of parchment over wooden boards, in contrast to a limp binding. ${ }^{23}$ Three books were apparently 'hairy' (pilosus): before Henry le Scrope was executed in 1415, for example, he bequeathed 'unum vetus missale, coopertum cum uno corio vituli pilosi' (one old missal, covered with one hairy calfskin). ${ }^{24}$ The word probably referred to skin with some or all of the animal's hair left on it, as in a very few surviving bindings. ${ }^{25}$ Taken together, then, these records help us picture the varied, colourful and sometimes recognisably animalistic exterior surfaces which books presented to readers. Their descriptions give us a better sense for the possible visual and tactile landscape of books and personal libraries in later medieval England.

Mentions of writing supports - the materials of the leaves which transmitted text rather than the bindings which protected it-offer a more complex picture which demands more interpretation. Seventy descriptions address this feature. Fifty-five of these specify books copied on paper, while eleven specify parchment and four describe mixed parchment and paper. Does this mean that paper was more common than parchment? I would suggest instead that, because books important and valuable enough to be bequeathed or inventoried were more often copied on parchment, when such an important book was copied on paper that fact could be used to help future readers find it. If a book’s paper leaves are explicitly noted, that book has a higher chance of being described as 'a quire' (quaternus) or a book 'in quires’ (in quaterno). (I translate quaternus as 'quire' throughout, but in these records the word probably denoted a limp binding rather than a book in dispersed or loosely gathered quires. $)^{26}$ Paper books which have their contents specified are also more likely than other books to be collections of a testator's sermons or lectures, manuscripts which might have been assembled haphazardly and over an extended period of time, from booklets which were initially expected to be ephemeral. For instance, the description in Thomas de Farnylawe’s 1378 will of 'quaternum meum de papiro, qui incipit cum illo sermone "in Memoria eterna 
erit justus"' (my quire of paper, which begins with that sermon [on] 'the just shall be in eternal memory’) sounds like a manuscript of this kind. ${ }^{27}$ As might be expected, references to paper books are significantly more common in fifteenth-century descriptions than in fourteenth-century descriptions. Orietta Da Rold has pointed out, however, that it is risky to generalize about the value and proliferation of paper, which was already in documentary use in England in the early fourteenth century, and cannot simply be pigeonholed as a material for transmitting text more cheaply. ${ }^{28}$ So the rising number of mentions of paper in the fifteenth century probably does not trace out in any simple way the growth of the use of paper in book production. Rather, this is probably evidence of a shift in attitude: the gradual acceptance of paper as a writing support appropriate for the kind of book important or valued enough to be bequeathed or inventoried. To complicate matters further, in this sample parchment is also mentioned more frequently as a writing support as time passes. Parchment is specified as a writing support three times in records from the fourteenth century, while in records from the first half of the fifteenth century it is mentioned nine times. ${ }^{29}$ The small size of the numbers involved and the sample's limitations mean that this observation can only be suggestive, but it suggests a situation in which parchment itself was becoming slightly more noticeable by contrast with paper, as the latter material became more acceptable. Perhaps readers paid more attention to writing supports in general in the fifteenth century, just as readers today, after the advent of e-books, might be more alert to the physicality of codices. ${ }^{30}$

\section{Codicological attitudes}

Records of writing supports might also, then, reveal something about readers' expectations: what they thought a normal book’s writing support should be. Besides a range of facts about missing books, book descriptions record particular medieval readers' experiences, their uses of their senses as they saw and handled texts, and their ways of imagining books. In other 
words, these descriptions can tell us something about folk-codicological attitudes, about the mechanisms and priorities of later medieval English bookishness. Physical descriptions can reveal these things because they are identification tools: recorders reached for features which would distinguish individual books. ${ }^{31}$ While individual descriptions might offer only brief glimpses of the properties which were most commonly used to identify manuscripts, they can, gathered together, offer a broader view of the ways in which books were experienced. So: which perceptible qualities did bookish people in later medieval England reach for when identifying books? Within this sample, the most significant answers are, in descending order of importance: size (414 descriptions), the colour or material of the binding (347), and age (167).

The prominence of size and binding seems natural: these are visible and tangible properties. Looking and touching would be crucial in the process of sorting through private collections, which might often have lacked organizational systems. The books identified by their size split evenly between those which were large (212) and those which were small (202). So small books could be valued and thought worth mentioning: the 1368 will of John de Grandisson, Bishop of Exeter, refers to 'pulchram parvam Bibliam meam’ (my beautiful small Bible). ${ }^{32}$ Indeed, as with other kinds of information technology, when a book was small enough its diminutive size became notable and valuable in its own right: Chiara Ruzzier has observed with reference to Bibles that producing books which were miniaturized required skill, planning and expensive labour. ${ }^{33}$ One common category of book, the portable breviary called a portiphorium or porthors, was nominally identified by its portability: both of its names mean something which can be 'carried outside'. ${ }^{34}$ So, for example, the 1458 will of Sir Thomas Chaworth includes 'a litel Portose, the which the saide Sir Thomas toke with hym alway when he rode': this was evidently a plausible and appropriately pious statement whether or not it was wholly true. ${ }^{35} \mathrm{~J}$. A. Burrow observed that the portiphorium's portability 
might characterize the suspicious convenience of the oaths sworn by the monk and the merchant's wife on a 'portehors' in Chaucer's Shipman's Tale. ${ }^{36}$ Perhaps there is also an implicit folk-codicological contrast here with the static, secure account books which detain the merchant at the same moment. ${ }^{37}$ Shape, as well as size, could prompt comment: three books are described as 'thick' (spissus), demonstrating that at least some recorders could identify a codex which had an unusual amount of depth for its width and height, and expected the same ability in their own readers. ${ }^{38}$ Two examples appear in the unusually detailed book descriptions left in the 1361 will of William Doune, archdeacon, who left 'magni libri et spissi valde’ (a great and very thick book) of legal information, alongside a miscellany which Doune called:

magnum quaternum, immo librum quem solebam mecum cariare scriptum in parte in percameno et in parte in papiro, in quo signaui et remisi per dicciones quasi per alphabetum, vbi reperientur dicta Innocencii et Archidiaconi in rosario et materie scripte in dicto libro spisso.

(the great quire or book which I was wont to carry about with me, written partly on parchment and partly on paper, wherein I have noted and arranged the matter under headings, as it were alphabetically; and here will be found the sayings of Innocent and of the Archdeacon in rosario and the matters written in the said thick book.) ${ }^{39}$

This is an unusually detailed description, an extended analeptic picture of both a book's physical construction and its place in its owner's life. Apparently Doune’s book was, despite being great and thick, a portable tool for rapid, alphabetized reference. Its construction of mixed parchment and paper, in what was probably a limp binding rather than literally a single quire, hints that it might have been slightly haphazard and unplanned in origin: perhaps it began as a less well-organized collection of writings and grew into something disproportionately spissus. The third example, from a different owner, was 'Quaternus 
spissus, cum diversis Processibus' (A thick quire, containing various proceedings), in a 1395 list of the possessions of a secular priest. ${ }^{40}$ Noticeable thickness seems, from the few pieces of evidence here at least, to have been a feature of the personal legal miscellanies of churchmen, which often incorporated some paper and sat within limp bindings. Taken together, the treatment of size and shape in this evidence suggests a widespread and sometimes discriminating sense for writing as a physically handled thing.

Similarly, age's relatively frequent appearance as a distinctive feature confirms that later medieval readers had some sense for new and old: they could spot an object made in the past just as we can, and indeed some readers probably had more examples to hand than we do. Two 'old' (vetus) books in the St Augustine's catalogue survive, and they date from the ninth and tenth centuries, suggesting that for that cataloguer, at least, a book might have been 'old' through perceptible historical distance rather than a simple decline in its condition. ${ }^{41}$ That said, some books certainly were physically declining: a 1423 inventory of the books of Henry Bowet, Archbishop of York, deploys the adjective caducus (falling [to bits]) for two volumes and describes another book as 'vetere et debili' (aged and worn out). ${ }^{42}$ However, mentions of new books (novus, novel, newe) are in fact more common than mentions of old ones (102 descriptions against 65). As with the descriptions which specify that books were copied on paper, these records were probably meant to identify by describing features which distinguished books from their peers, and so the prevalence of 'new' perhaps indicates that in some circumstances new books were rarer and more notable than old ones. This finding supports recent suggestions that readers were accustomed to second-hand copies and that medieval owners expected that some substantial books, at least, could outlive them. ${ }^{43}$

Mentions of script as a feature distinct from age are rare. The sample of descriptions gathered by Cavanaugh contains two references to anglicana and one to textualis. One of the books copied in anglicana contained canon law, and the other did not have its contents 
specified, perhaps suggesting that, for the recorder concerned, the script alone was enough to identify the book. ${ }^{44}$ The book copied in textualis was an ordinal owned by an important churchman. ${ }^{45}$ In a handful of cases recorders mentioned the size of script, specifically, in all the instances I have found, large script. ${ }^{46}$ Tantalizingly, one description of a book copied not just in two hands, but in 'ij maner hands' might be a textual acknowledgement of a hierarchy—or at least a variety—of scripts. ${ }^{47}$ From this evidence, then, those handling books were capable of recognizing and thinking about script, but only rarely relied on it as a distinguishing feature, probably because it took more effort to check a book’s handwriting. Recorders sometimes displayed signs of subjective judgement in their work, despite its seeming monotony. 109 descriptions mention quality in some way. 'Quality’ here is a catch-all category for descriptions which describe books as 'best', 'better', 'good', 'bad', 'worse' and 'worst': the spectrum from optimus to pessimus. Some books were apparently considered simply good or bad relative to a conception of books in general: one of Henry Bowet's manuscripts, for example, was, the description sighs, 'male scribitur' (badly written). ${ }^{48}$ More usually, however, writers reached for comparatives and superlatives, not just good and bad; and they often did so because they had to mention multiple manuscripts containing the same text, or texts with the same function. Someone might, for example, have to bequeath both their 'best psalter' and their 'other psalter'. Quality was, then, one way to taxonomize multiple books with matching contents or purposes, most commonly when a wealthy owner had books for use in religious observance or devotion in different contexts: multiple primers, psalters, portiphoria or missals. Qualitative discrimination of this kind might therefore have been, to some extent, a privilege of the very well-off: less wealthy book owners were probably sensitive to the stratification of book quality, but they had fewer duplicate copies, and therefore fewer reasons to express taste. The expression of taste might be one motivation for the small but distinctive subgroup of book descriptions in secular 
aristocratic wills which offer more details than were judged necessary to identify books in other records. A typical example from the 1399 will of Eleanor Bohun, Duchess of Gloucester, describes ‘un Cronike de Fraunce en Frauncois, ove deux claspes d’argent, enamayles ove les armes de Duc de Burgoign' (one chronicle of France in French, with two clasps of silver, enamelled with the arms of the Duke of Burgundy). ${ }^{49}$ It is possible that noble owners had many ornate books which could only be told apart by distinctions of decoration, so that these descriptions were written safeguards against the risk of confusion. The need to value books financially might also have shaped these texts. However, the records themselves might also sometimes have participated in an aesthetic of plenitude and ornament: if the presence of beautiful things was pleasurable for an owner and the members of their household, perhaps the act of listing them in detail was pleasurable too. These book descriptions' interest in exteriors, colours and materials—gold, silver, enamelling and various types of expensive cloth—also runs through the descriptions of clothing found in the same wills, and this interest is certainly consonant with Mary Carruthers's recent exploration of a 'medieval ordinary beauty' which was found in physical things and especially those things' exterior surfaces. ${ }^{50}$

Aesthetic language also surfaces in the handful of descriptions which call manuscripts beautiful. The sample size is small (fourteen descriptions) but the books which are most commonly identified by their beauty are books of canon law, which, as we know from surviving examples, could sometimes be luxuriously illuminated. ${ }^{51}$ The other examples are all types of book which could be produced in both large quantities and high quality: missals, a bible, a breviary and two prayer books. Apparently glossing too had some aesthetic value, or at least could be described aesthetically: a psalter is described as 'glosatum de pulcra manu’ (glossed by a beautiful hand) and another book of canon law was apparently 'pulcre apparitate’ (beautifully annotated). ${ }^{52}$ Unusually, there is a surviving book distinguished in a 
will as not just beautiful, but 'pulchrius' (more beautiful), so-stepping outside the sample of descriptions of lost books for a moment-it is possible to see what at least one later medieval inventorizer was describing. ${ }^{53}$ This is the 'Grandisson Psalter', a thirteenth-century production and another book which passed through Bishop Grandisson’s ownership: it is a small, personal manuscript $(c .250 \times c .160 \mathrm{~mm})$ but it is filled with magnificent miniatures, and the fact that today it has a name as well as a shelfmark attests to its impact on modern readers. ${ }^{54}$ Quality and beauty were, then, available categories of language for at least some of the people writing these documents: in subdued and intermittent ways, later medieval folk codicology is a body of aesthetic writings. Beauty does not appear in these writings in tangential digressions. Instead, explicit invocations of beauty are instrumental uses of language, aids to valuation or identification: 'this book is more beautiful than that one, this is the one I mean'. But 'beautiful' is not as straightforward a description as 'the one with the gold clasps', and so, even in an inventory compiled with an eye to sale, the deployment of the concept of beauty involves an element of subjectivity. These writings might, therefore, preserve a kind of practical aesthetics: the perception of beauty worked out in the habitual labour of taxonomizing books.

\section{Anticodicological attitudes}

For at least some recorders, then, the individuality of particular books was bound up in their beauty and quality; and, more generally, sight and touch were sometimes crucial in physically identifying books in folk codicology_-just as they are vital to modern academic codicology. What, though, of readers' and owners' attitudes towards writing's physicality? Work in manuscript studies tends to hold that medieval readers and owners were conscious of books as physical objects. Seth Lerer offers a cogent statement of this position in the 'critical fulcrum' for a recent, important collection of essays when he delineates the category of 'the 
premodern book: an object that [...] was understood to be an individual object in its own time', in implicit contrast to the interchangeable modern book, produced by processes which have 'decoupled the content from the artefact'. ${ }^{55}$ Later medieval readers and owners certainly could understand books as unique, physically individual objects. In the descriptions discussed above the physical individuality of the premodern book was necessary for the proper functioning of phrases such as 'le meillour portors graunt' (the better large porthors), descriptions which identified by contrast. ${ }^{56}$ The sense of specificity visible in these descriptions suits modern Anglophone scholarship: as that scholarship has become more consciously attuned to medieval manuscripts, a hallmark of our approach has been a focus on what Alexandra Gillespie, summing up scholarship a decade ago, called manuscripts’ ‘thickly meaningful particularity'. ${ }^{57}$ Every manuscript certainly is unique, and there is nothing inherently wrong with our tradition of close, detailed case studies. However, unlike modern researchers, later medieval readers and owners were under no obligation to be faithful to the nature of their physical books, and so conscious engagement with physical particularity is not the only attitude which medieval readers took to books. Using records of lost books-books which, appropriately, no longer possess any physical particularity of their own-it is possible to explore some alternative later medieval attitudes to the physical book.

According to the evidence surveyed here, readers and owners could elide physicality. The physical book is, after all, a delivery system for text, and records of a book’s physicality might be of limited use in a list: physical characteristics might not be sufficiently distinctive, and might change over time as bindings were worn down. Many descriptions therefore elide physicality even as they refer to it. For example, when a list mentions the purchase of 'Tota summa Thome de Aquino in quatuor voluminibus' (the whole Summa of Thomas Aquinas in four volumes), it reveals the existence of four physical codices but emphasizes the author: Aquinas's conceptual unity collapses the distinction a modern codicologist would see 
between four objects. ${ }^{58}$ A similar effect, negating the physical book by specifying it, is at work when descriptions note authors who are to be found 'in one volume' or 'in the same book’. A typical example picks out 'librum Ysidori super Ethimologias verborum, cum aliis libris beatorum Augustini et Bernardi, atque Boecii, in uno volumine' (Isidore’s book on the etymologies of words, with other books of the blessed Augustine and Bernard, and Boethius, in one volume. $)^{59}$ Lists composed using descriptions such as this one repeatedly refer to physical books, but do so only to list works which happen to be grouped in uno volumine or which were spread across multiple books. In such descriptions the material is sorted by named authors: readers were seeking content, not artefacts. The importance of authors to later medieval literary theory has been well recognized for some time, but they can be seen displacing the physical book in taxonomizing practice ${ }^{60}$ For a fuller picture of the elision of the physical in later medieval writing about books, it is worth considering all the medieval book descriptions which were surveyed for this study and then excluded because they contain no codicological observations. Around 7,600—95\%—of the documents gathered by Cavanaugh exclude any physical details, and all of their book descriptions are consequently absent from this study. Most of the time, the books held or donated by private owners were recorded and identified purely by their content. Later medieval readers and owners certainly could attend to and think about the physical book, but at times and in some contextsperhaps in the majority of times and contexts - they were capable of ignoring books’ physicality.

Even one of the seemingly physical categories noted above, the portiphorium or porthors, was affected by the elision of physicality. There certainly were small portiphoria, but over time the word came to mean the gathering of texts typical of a portiphorium, without automatic reference to the book’s physical portability. There are plenty of references to portiphoria which were not portable, such as 'portiphorium notatum, in duobus voluminibus' 
(a portiphorium with notation, in two volumes), and as a consequence recorders could find themselves listing 'portiphorium portatile' (a portable portiphorium). ${ }^{61}$ Here content had come to obscure artefact to such an extent that the artefactual aspect of the portiphorium-its convenient size—-had to be restated.

Descriptions of books in private ownership can be usefully compared on this point to the evidence of institutional catalogues. Individuals' wills and inventories record physicality more often than institutions' catalogues, probably because finding and identifying books in less well-organized private collections could be a greater challenge. When descriptions mention multiple physical aspects of a book, their syntax perhaps anticipates this use. The reader who learns of a 'litill rede primer lynyd with blak bawdekyn' has been taken from the most quickly-grasped facets of the book's physical manifestation-it is little, and red—-to the less immediately obvious. ${ }^{62}$ Institutional libraries, by contrast, were better-placed to develop permanent organizational tools which freed readers from codicology. There are, it is true, institutional records which attend to physicality. However, references to the physical in institutional documents are most common when those documents are not programmatic catalogues, but more occasional lists from specific, more haphazard situations. So, for example, a fragment of an otherwise lost library book list, possibly from the Cluniac priory at Bermondsey, frequently includes physical details: a codex containing works by Orosius is ‘uetus non ligatum' (old, not bound), two books are 'parui rubei’ (small, red), and so on. ${ }^{63}$ This list was not, however, a catalogue, and Richard Sharpe suggests from its hand and format that it was not designed for readers' reference. It contains some loan records and might, he proposes, have been a stock list. ${ }^{64}$ So this list was probably needs-driven, occasional librarians' information: closer to the situation of a will or personal inventory.

The fourteenth century saw the appearance of institutional library catalogues which were much more systematic. The pre-existing and continuing tradition of informal book lists 
already 'centred on the contents, with the occasional use of physical adjuncts', but the newer catalogues tended to exclude codicological information almost entirely. ${ }^{65}$ Readers in a library with a sophisticated catalogue could read an entry such as '.N.XIII. / Tractatus de ordine monachorum nigrorum’ (.N.XIII. / a treatise about the Rule of the Black Monks), and navigate quickly to the book concerned by looking for the thirteenth book in the $\mathrm{N}$ section. ${ }^{66}$ This example is from the catalogue of the library of the Premonstratensians in Titchfield, and if these hypothetical readers were familiar with the library or had bothered to consult the catalogue's introduction they would not even have searched the room for N: they would have known to head for the fourth and fifth shelves of the library's fourth set of book-cases, on the north side of the room. ${ }^{67}$ Of the 294 physical descriptions of now-missing books I have found in the catalogue of the library at St Augustine’s—-from a total of around 1750 discrete catalogued books —233 simply record that a book is in a limp binding. ${ }^{68}$ Only two descriptions, meanwhile, mention colour. The field of codicological view in this catalogue has narrowed to the binding structure alone. The catalogue of the library of the Titchfield Premonstratensians displays the same tight focus on the presence of limp bindings, with little interest in other physical features.

A later and fuller representative of this tendency, from the turn of the sixteenth century, is Thomas Betson's magnificent catalogue to the library of the brethren of Syon Abbey (a library which included, in Betson’s time, early printed books alongside manuscripts). This catalogue records information about the contents of many books, yet only rarely mentions any physical aspect of any book. It maintains this lack of interest in books’ physicality despite interfacing with two physical features of the library: title plates in the librarian's hand, nailed into the books' covers, listing contents, secundo folio records and provenance information; and physical finding tabs, which were sometimes themselves labelled. ${ }^{69}$ Labels and finding tabs were both widespread devices, but their use in the library 
of the Syon brethren was unusually programmatic. Establishing this system entailed much physical effort, cutting, labelling and nailing. Betson himself was an able practitioner of collation, which is perhaps codicology's most foundational act, and he was probably the letter-writer who instructed a group of nuns to keep their books 'clene and hole and when tyme shall requyre repayre hem'. ${ }^{70}$ Nevertheless, the end result of all this physical labour, directed by a curatorial reader who understood the physical book, was that other readers were saved from having to think about books’ physicality. By shuffling codicological facts about manuscripts conveniently out of the way, these tools served and encouraged reading practices which focused on texts and elided books. Similarly, the Franciscans' so-called 'union catalogue', the fourteenth-century Registrum Anglie (in fact a selective listing of patristic works and Biblical commentaries in other organizations' libraries) was sorted by author and identified locations, not particular manuscripts. ${ }^{71}$ Indeed, Mary and Richard Rouse found evidence that its compilers behaved anticodicologically during its construction, rearranging works from codex order into author order when drafting their reports from individual repositories. ${ }^{72}$ So, then, during this period institutions were removing folk codicology from their finding aids, which became distinctively different from the records generated by private owners. The opposition which Michael Camille once perceptively drew between the 'intimate, interactive and corporeal' medieval library and the ‘disembodied, panoptic display’ of the modern library had in fact already begun to separate personal and institutional collections. ${ }^{73}$ Taken together, these examples of institutional practice reveal that when bookish people had more resources—-time, stability, co-workers, organizational backingthey used those resources to avoid dealing with books' physicality. It was only when resources were scarce that book descriptions fell back upon folk codicology.

Much of this elision of the physical was carried out unconsciously, and was driven by pragmatic considerations. I am not arguing that medieval recorders set out deliberately to 
exclude physical details. They simply had busy lives in which they had to list books for immediate, practical purposes. This pressured quality is what makes recorders' work revealing. Forced by circumstances to prioritise different qualities for spatial and temporal efficiency, they prioritised texts over books, thereby reminding us that medieval readers frequently ignored the details over which we pore. Attitudes can exist without being actively theorized by those who hold them, and a lack of conscious examination might indicate that an attitude is particularly pervasive and significant.

When owners and readers did consider manuscripts’ physicality and particularity they sometimes encountered these characteristics as problems to be solved or as limitations to be regretted. Descriptions in wills and inventories show medieval readers observing manuscripts' particularity in terms of physical instability. So, for example, descriptions mention books which have been damaged or have lost contents: a recorder might note a book ‘que deficit unus quaternus’ (which lacks one quire) ${ }^{74}$ They mention books which are still under construction, too: for instance, the 1404 will of Henry Brokeland, canon of Exeter and rector of Moreton, includes an incomplete book which his executors are expected to have finished and chained to Brokeland's choir stall. ${ }^{75}$ Later medieval readers and owners could, then, be well acquainted with literature's inevitable entropy in its particular physical manifestations. ${ }^{76}$ This instability was not desirable, and records also offer evidence of later medieval struggles against it. Even as such descriptions recorded readers' alertness to the messiness of the individual artefact, they simultaneously recorded discomfort with that messiness, which is often discussed as though it is a stumbling-block on the path to an idealized book. Readers could imagine this ideal book and could aspire to own it. So, even when descriptions are clear that a book is incomplete, that incompleteness is bound up with the idea (or hope) that in the future it will become complete. For instance, a book might be 'adhuc non perfectum in quaternis' (still incomplete, in quires); ${ }^{77}$ in 1391 the cleric John 
Percehay left a 'librum vocatum Trevet, nondum plene scriptum' (a book called Trevet, not yet fully copied); ${ }^{78}$ and Grandisson donated to Exeter Cathedral a book 'nondum posita in asseribus' (not yet put in boards). ${ }^{79}$ The 1382 will of Thomas de Lexham, a fourteenthcentury Hereford Cathedral canon, includes some not atypical forethoughts: one gloss on the gospels was to be bequeathed 'si scriptus fuerit tempore mortis mea' (if it be copied at the time of my death), and failing that the recipient was to receive 'librum meum de gestis anglorum si fuerit scriptus et ligatus' (my book about the deeds of the English, if it be copied and bound). ${ }^{80}$ The same imaginative capacity appears in some of the examples of instability offered above: a book can only be said to lack one quire if it is being compared against an imagined ideal book, and a book can only be thought 'not quite complete' when it might one day be complete. Readers were sometimes forced to see the book as physical, time-bound artefact, but they often would have liked to see the book as a fixed, complete and ideal unit of content.

Those of us who work primarily by examining particular physical artefacts are perhaps sometimes too eager to read our fascination with messy, thickly particular manuscripts back into later medieval minds. In fact it was possible for a medieval writer to describe 'codices’ as 'non sunt nisi supposicione pro tempore necessarii’ (nothing but substitutes, necessary for a time), as John Wyclif did. ${ }^{81}$ Of course, Wyclif was not primarily commenting on the idea of the physical book, but rather making a theological point: that scripture is not limited to its material containers, is not undermined by the errors of human scribes, and so is portable across linguistic and physical boundaries. ${ }^{82}$ His breezy dismissal of the physical book can however still be a useful corrective. It is not far from Stephen G. Nichols's polemical ventriloquization, during the now old debate over the 'New Philology', of a traditional textual-critical view of the manuscript book: 'an irritating obstacle to the recovery of a satisfactory text' ${ }^{83}$ Attitudes towards the physical book did not have to match 
the unstable, physically particularized states of books themselves. Indeed, from the evidence of folk codicology, attitudes towards the physical book were sometimes dissatisfied reactions against books themselves. While in functional terms later medieval culture certainly relied on unfinished, individual and complexly messy books, owners and readers did not necessarily enjoy this situation, and their own book descriptions register their struggles against the limitations of the physical manuscript. Books’ particular physical inadequacies could drive readers to textual idealism.

\section{Conclusion}

It might seem strange to begin with a desirous search for missing manuscripts only to end with the rejection of books' physicality by some later medieval readers themselves—although the fiend encountered in 'Canon Alberic’s Scrap-Book' is certainly unwelcome, and Dennistoun eventually destroys the particular (postmedieval) page in which it dwells. I am certainly not suggesting that readers in this period were incapable of thinking, sometimes enthusiastically, about the physical book, still less that we should not study their conscious interactions with books’ physicality. I am, however, suggesting that the book was not always 'understood to be an individual object in its own time'. Our understanding of later medieval reading and later medieval manuscripts might benefit from a wider sense of the choices readers had in their relationship with the physical book. They could think about books’ physicality, but they could also ignore or resist it as they busied themselves with routine administrative or intellectual labour. They could conceive of ideal, complete and perfect books, and they could choose to organize their reading around topics and authors, with very little reference to the material objects which enabled their access to texts. Manuscript studies could perhaps attend more to readers who sought works and authors, ignoring the system of texts and books which underpinned their search. It could perhaps attend more, too, to readers who were forced to respond to disjunctions between content and artefact, readers who found 
the book to be an obstacle or hindrance. Such attention should not threaten the study of conscious or enthusiastic medieval engagements with the physicality of books. Rather, it should make such engagements more notable as active choices, made in the context of alternative possibilities.

The records examined here are individually clipped and challenging, but reading this material on a large scale reveals traces of the appearance, size, shape and materials of missing books, and traces left by the practices of looking and touching with which later medieval people sorted through their reading material. Even hints of judgement and the appreciation of beauty can be detected in the routine working-out of practical problems in folk codicology, as recorders tried to sort and identify books. Attitudes towards physicality itself were driven by contradictory impulses towards both an appreciation of the particular material object and an idealization of the textual content. This contradiction asks us to expand our history of the idea of the book and to multiply our models for medieval readers searching out texts, handling them, listing them, passing them on, and sometimes (even!) reading them. Most of the books which once existed in medieval England are gone for good, but the vexing textual spectres which remain can bring us valuable evidence, justifying the effort of necromancy. 


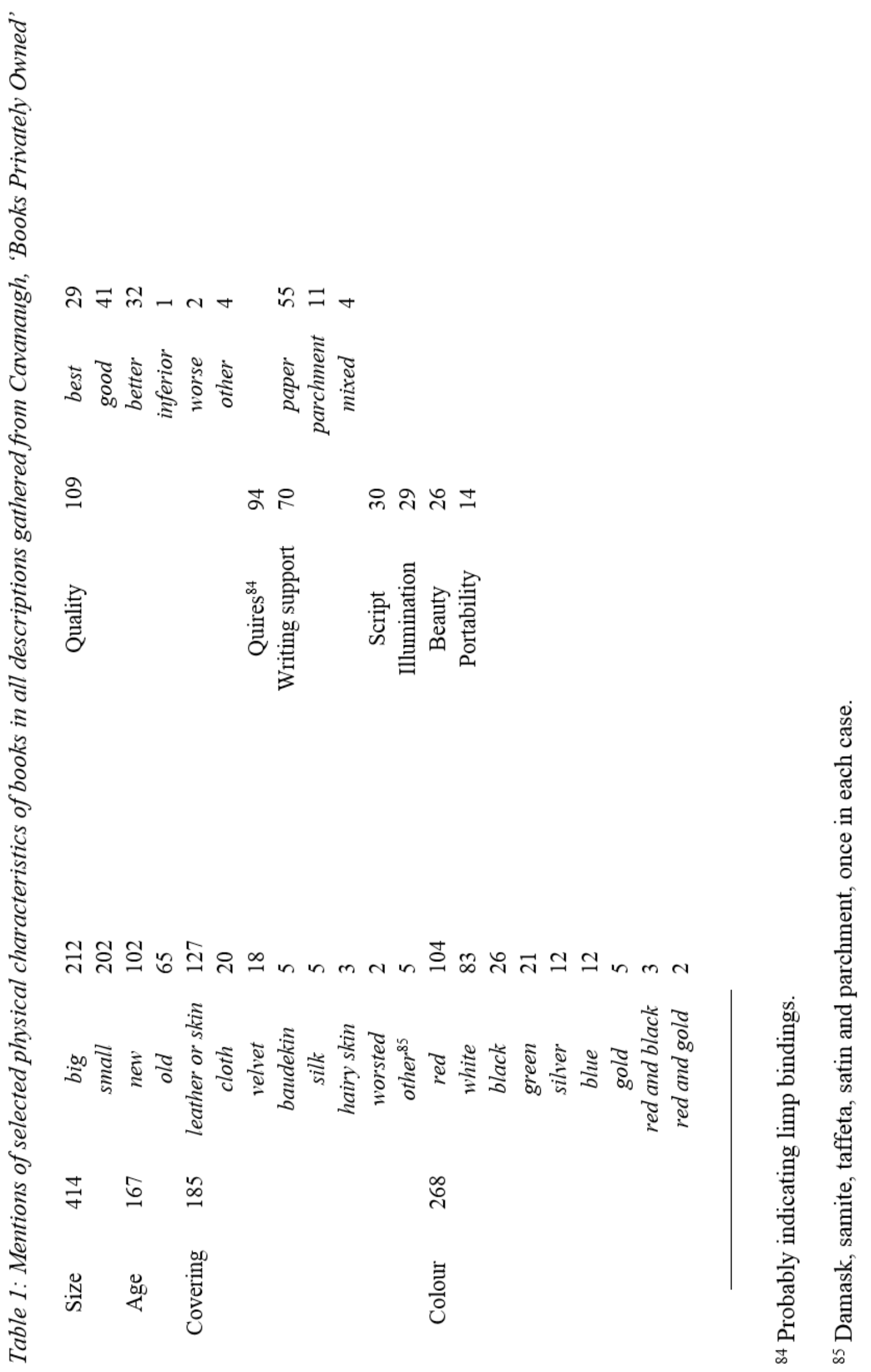


${ }^{1}$ Ghost Stories of M. R. James, pp. 8-9. James probably named Dennistoun after a real collector: Edwards, ‘M. R. James, “Canon Alberic’s Scrap-Book”, and “Dennistoun”’. I am grateful to Hannah Ryley, Daniel Wakelin and the anonymous reviewers for The Mediaeval Journal for reading this piece and making many helpful suggestions.

${ }^{2}$ Scattergood, Manuscripts and Ghosts, p. 18. See also the reflections on the use of haunting by medievalists and by theorists in Novacich, Shaping the Archive, pp. 148-53.

${ }^{3}$ The real Dennistoun created a noted album of excised art, which was itself cut up in 1984: Wieck, 'Folia Fugitiva’, p. 240. Collectors’ scrap-books of this type are hard to find today, perhaps because the act of disassembly seems more acceptable to some owners when the scraps within have already been cut from their original context. Albums of fragments have also been created by libraries to hold loose material: see, for example, Oxford, Bodl. Lib., MS Rawlinson D. 913 and the examples listed in Ker, Pastedowns in Oxford Bindings, p. xv. The cutting-up and dispersal of medieval manuscripts continues in the twenty-first century and can sometimes be observed in progress on eBay: Treharne, 'The Broken Book II: From a Book of Hours to a Book of Bits’.

${ }^{4}$ Bale, 'Belligerent Literacy, Bookplates and Graffiti', p. 89. Estimates of the proportion of manuscripts which are lost vary in method and result, but are usually high. See for example: D’Avray, Medieval Marriage Sermons, pp. 16-20; and Sargent, 'What Do the Numbers Mean?' See also the provocative, if problematic, study in Buringh, Medieval Manuscript Production, 179-251.

${ }^{5}$ There are a few precedents for. Wilson, Lost Literature of Medieval England, uses some manuscript record evidence but considers missing texts rather than missing books. Cartlidge, 'Imagining X', which is in part a response to Wilson, offers a speculative but precise study of one missing book. 
${ }^{6}$ Hanna, 'Problems of “Best Text” Editing', pp. 88-89.

${ }^{7}$ Wakelin, 'William Worcester Writes a History of His Reading'.

${ }^{8}$ Hibbard, ‘The Books of Simon de Burley, 1387’, p. 171. Translations here and below are mine unless otherwise specified. Capitalization in quotations has been silently regularized, and manuscript abbreviations have been silently expanded. Translations from the Vulgate are those of the 1582/1609-10 Douay-Rheims translation with silently modernized orthography.

${ }^{9}$ Burgess, ‘Late Medieval Wills and Pious Convention’, pp. 29-30.

${ }^{10}$ Bishops' wills, for example, do not necessarily read differently to other wills, but a set of specifically episcopal considerations affected both their creation and the probate process that was applied to them: Testamentary Records of the English and Welsh Episcopate, ed. by Woolgar, p. xxxiv; pp. xx-xxxiii and xliv-xlix.

${ }^{11}$ Rosenthal, 'Clerical Book Bequests', pp. 337-341; Spedding, 'Hoc est testamentum', pp. 283-87.

12 This resource is not perfect (see Cavanaugh, ‘A Study of Books Privately Owned in England', pp. 9-20 for Cavanaugh's own qualifications). However, it continues to be referenced frequently in scholarship and, despite remaining unpublished, can be found on the shelves of three national libraries and eight other major research libraries in the UK. As individual references below will be to Cavanaugh’s sources, which I have checked in each case quoted, I should record here the fact that her work was a vital map to the material.

${ }^{13}$ St Augustine's Abbey, ed. by Barker-Benfield. This catalogue, created around the beginning of the fifteenth century, survives in one supplemented copy in the late fifteenthcentury transcript in Dublin, Trinity College, MS 360. I have cross-referenced the few descriptions which Cavanaugh quotes from the previous edition of this catalogue (Ancient Libraries of Canterbury and Dover, ed. by James), and avoided counting them twice. I am pursuing systematic surveys of other institutional catalogues as part of a larger project. 
${ }^{14}$ Moretti, ‘Style, Inc’; Gasnault, ‘Observations paléographiques et codicologiques’.

${ }^{15}$ Gumbert, 'Fifty Years of Codicology', p. 525; Goldberg, 'The Fashioning of Bourgeois Domesticity in Later Medieval England’, p. 126.

${ }^{16}$ Meale, 'Laywomen and their Books’, pp. 130-32.

${ }^{17}$ Collection of All the Wills, ed. by Nichols.

${ }^{18}$ Moretti, 'Slaughterhouse of Literature’, p. 208.

${ }^{19}$ Szirmai, Archaeology of Medieval Bookbinding, pp. ix-x; Gillespie, 'Bookbinding', p. 158.

${ }^{20}$ For the frequency of mentions of selected physical features in the descriptions I have collected, see Table 1, below.

${ }^{21}$ As the terminus ad quem for Cavanaugh's study is c.1450, the replacement of alumtawed skin by tanned, stamped leather in the middle of the fifteenth century (Gillespie, 'Bookbinding', pp. 169-71) is unlikely to register in this sample.

${ }^{22}$ Gasnault, ‘Observations paléographiques et codicologiques’, pp. 273-4.

${ }^{23}$ Testamenta Eboracensia, ed. by Raine and Clay, II (1855), p. 79.

${ }^{24}$ Fœdera, conventiones, literce, et cujuscunque generis acta publica, ed. by Rymer, Sanderson and Holmes, IV, II, p. 132.

${ }^{25}$ See for example Oxford, Bodl. Lib., MS e Musaeo 198*.

${ }^{26}$ Ker, Books, Collectors and Libraries, p. 306 n. 26, p. 358 n. 56.

${ }^{27}$ Testamenta Eboracensia, ed. by Raine and Clay, I (1836), p. 102. The text here is Psalm 112. 7 (Vulgate 111. 7).

${ }^{28}$ Da Rold, 'Materials', pp. 23-25.

${ }^{29}$ As might be expected given increasing documentation over time and the better survival chances of newer documents, fifteenth-century records are disproportionately represented in Cavanaugh’s study, despite her terminus ad quem of 1450. However, fifteenth-century 
mentions of parchment and paper are even more common in my data than one would expect given this distortion.

${ }^{30}$ Baron, Words Onscreen, pp. 131-33, p. 266.

${ }^{31}$ Rouse and Rouse, ‘Will Power’, pp. 211-12.

${ }^{32}$ The Register of John de Grandisson, ed. by Hingeston-Randolph, III (1899), p. 1554.

${ }^{33}$ Ruzzier, 'The Miniaturization of Bible Manuscripts in the Thirteenth Century’, pp. 12425.

${ }^{34} M E D$, s.v. 'portiforme (n.)' and 'porthors (n.)'; and OED, s.v. 'portiforium (n.)' and 'porteous (n.)'.

${ }^{35}$ Testamenta Eboracensia, ed. by Raine and Clay, II (1855), p. 227. Only three of Chaworth’s books survive, and all are large: Cole and Turville-Petre, 'Sir Thomas Chaworth’s Books’, pp. 21-23.

${ }^{36}$ Chaucer, Canterbury Tales, in The Riverside Chaucer, ed. by Benson, ll. VII.131 and 135; Burrow, Gestures and Looks, p. 17.

${ }^{37}$ Chaucer, Canterbury Tales, ll. VII.82-85.

${ }^{38}$ DMLBS, s.v. 'spissus' 1b. Gasnault only finds two instances of books so described in his single-library sample: ‘Observations paléographiques et codicologiques’, p. 270.

${ }^{39}$ Thompson, 'The Will of Master William Doune', p. 282; the translation here is Thompson's (p. 264).

${ }^{40}$ Testamenta Eboracensia, ed. by Raine and Clay, III (1864), p. 6.

${ }^{41}$ St Augustine’s Abbey, ed. by Barker-Benfield, BA1.137 (p. 419), BA1.851 (p. 883), now Oxford, Bodl. Lib., MS Bodley 426 and London, Lambeth Palace Lib., MS 414 respectively.

${ }^{42}$ Testamenta Eboracensia, ed. by Raine and Clay, III (1864), p. 77; DMLBS, s.v. ‘caducus’ 2 and 4 a. 
${ }^{43}$ Rundle, 'Habits of Manuscript-Collecting’, pp. 111, 114; Sargent, 'What Do the Numbers Mean?’, pp. 214-17.

${ }^{44}$ Hemingby’s Register, ed. by Chew, pp. 110-111; Testamenta Eboracensia, ed. by Raine and Clay, I (1836), p. 17.

${ }^{45}$ Register of Henry Chichele, ed. by Jacob and Johnson, II (1937), p. 80.

${ }^{46}$ A collection of the works of Peter Lombard in the will of Robert Ayscogh: Emden, $A$ Biographical Register of the University of Cambridge, p. 27. Three psalters in large script: Catalogi veteres librorum ecclesiae cathedralis Dunelm, ed. by Botfield, p. 119; Testamenta Eboracensia, ed. by Raine and Clay, I (1836), p. 17, III (1864), p. 6; and Charles and Emanuel, 'Notes on Old Libraries and Books’, p. 356.

${ }^{47}$ Register of Henry Chichele, ed. by Jacob and Johnson, II (1937), p. 411; my emphasis.

${ }^{48}$ Testamenta Eboracensia, ed. by Raine and Clay, III (1864), p. 77.

${ }^{49}$ Collection of All the Wills, ed. by Nichols, p. 181.

${ }^{50}$ Carruthers, Experience of Beauty in the Middle Ages, pp. 178-87.

${ }^{51}$ L’Engle and Gibbs, Illuminating the Law.

${ }^{52}$ [Anonymous], 'Report of the Committee', p. 418; Register of Walter de Stapeldon, ed. by Hingeston-Randolph, p. 563. By my count, the presence or absence of glossing is recorded in 149 descriptions in Cavanaugh: I excluded these from the general survey, as glossing is not strictly speaking a codicological feature, but they demonstrate glossing's significance for at least some readers.

${ }^{53}$ Register of John de Grandisson, ed. by Hingeston-Randolph, III (1899), p. 1550.

${ }^{54}$ BL, MS Additional 21926.

${ }^{55}$ Lerer, 'Bibliographical Theory and the Textuality of the Codex’, pp. 19, 18; Lerer's emphasis. 
${ }^{56}$ Inventory of goods left by Richard FitzAlan (c.1313-1376), third Earl of Arundel:

London, Lambeth Palace Library, Register of Archbishop Simon Sudbury, fol. 94 .

${ }^{57}$ Gillespie, ‘The History of the Book’, p. 250.

${ }^{58}$ Cambridge, Jesus College, MS 57, fol. $168^{\mathrm{v}}$; transcribed in James, A Descriptive

Catalogue of the Manuscripts in the Library of Jesus College, Cambridge, p. 91.

${ }^{59}$ Testamenta Eboracensia, ed. by Raine and Clay, I (1836), p. 365.

${ }^{60}$ Minnis, Medieval Theory of Authorship.

${ }^{61}$ Testamenta Eboracensia, ed. by Raine and Clay, I (1836), p. 195; Register of Henry

Chichele, ed. by Jacob and Johnson, II (1937), p. 335.

${ }^{62}$ Lincoln Diocese Documents, ed. by Clark, pp. 50-51.

${ }^{63}$ Oxford, Bodl. Lib., MS Bodley 751, fol. $\mathrm{i}^{\mathrm{r}-\mathrm{v}}$ : this fragment itself now only survives as a flyleaf in a fifteenth-century binding; English Benedictine Libraries, ed. by Sharpe and others, B10.86 (p. 30), B10.92 (p. 31).

${ }^{64}$ English Benedictine Libraries, ed. by Sharpe and others, p. 22.

${ }^{65}$ Sharpe, 'Library Catalogues and Indexes’, pp. 201, 202-217.

${ }^{66}$ Libraries of the Cistercians, Gilbertines and Premonstratensians, ed. by Bell, P6.173 (p. 237).

${ }^{67}$ Libraries of the Cistercians, Gilbertines and Premonstratensians, ed. by Bell, pp. 18384.

${ }^{68}$ St Augustine’s Abbey, ed. by Barker-Benfield, p. xcv; for the total number of books recorded in the catalogue see p. 5.

${ }^{69}$ Hamel, Syon Abbey, pp. 103-6. Finding tabs of this sort were not uncommon but tabs which were programmatically applied to a whole collection, and frequently labelled, were rare: Sawyer, ‘Navigation’. 
${ }^{70}$ Betson can be seen recording shifts in quiring in his notes: Syon Abbey, ed. by Gillespie, p. xlviiii. Durham, Durham University Lib., MS Cosin V.iii.16, fol. $118^{\mathrm{v}}$, transcribed in Doyle, ‘A Letter Written by Thomas Betson’, p. 257.

${ }^{71}$ Registrum Anglie, ed. by Rouse and Rouse.

${ }^{72}$ Registrum Anglie, ed. by Rouse and Rouse, p. lxxxvi. I adapt the adverb ‘anticodicologically’ from Smith’s description of Piers Plowman as a poem with a ‘strong anticodicological tendency': 'The Shadow of the Book', p. 204.

${ }^{73}$ Camille, ‘The Book as Flesh and Fetish', p. 40.

${ }^{74}$ London, Lambeth Palace Library, Register of Archbishop William Courtenay, I, fol. $204^{\mathrm{r}}$.

${ }^{75}$ Register of Edmund Stafford (A.D. 1395-1419), ed. by F. C. Hingeston-Randolph, p. 382.

76 'Entropy’ is not a particularly fanciful metaphor here, for one preoccupation in studies of manuscript loss is the calculation of medieval manuscripts’ average half-life: Buringh, Medieval Manuscript Production, p. 238.

${ }^{77}$ London, Lambeth Palace Library, Register of Archbishop Simon Islip, fol. 122r .

${ }^{78}$ Testamenta Eboracensia, ed. by Raine and Clay, I (1836), p. 164.

${ }^{79}$ Oliver, Lives of the Bishops of Exeter, p. 317. By no means all complete books were bound in boards, but evidently a binding in boards was anticipated for this example. Grandisson was capable of thinking in a detailed way about the physical care of books on occasion, for he included detailed instructions on the handling of service books in his statutes for the grand collegiate church he established at Ottery St Mary in 1338, stipulating careful opening and prohibiting the use of 'digitis sputo tinctis' (fingers tinged with spittle) in turning the pages: The Collegiate Church of Ottery St Mary, ed. Dalton, p. 162.

${ }^{80}$ Register of Archbishop William Courtenay, I, fol. 204 . 
${ }^{81}$ John Wyclif’s “De veritate Sacrae Scripturae, ed. Buddensieg, I, p. 235.

${ }^{82}$ Levy, 'The Place of Holy Scripture in John Wyclif's Theology', pp. 36-37.

${ }^{83}$ Nichols, 'Philology and its Discontents', p. 117. 


\section{Works Cited}

\section{Manuscripts}

Cambridge, Jesus College, MS 57

Dublin, Trinity College, MS 360

Durham, Durham University Library, MS Cosin V.iii.16

London, Lambeth Palace Library, MS 414

—

—_, Register of Archbishop Simon Sudbury (no shelfmark)

_

London, British Library, MS Additional 21926

Oxford, Bodleian Library, MS Bodley 426

—

—, MS e Musaeo 198*.

—, MS Rawlinson D. 913

\section{Primary Sources}

The Ancient Libraries of Canterbury and Dover: The Catalogues of the Libraries of Christ Church Priory and St. Augustine's Abbey at Canterbury and of St. Martin's Priory at Dover, ed. by M. R. James (Cambridge: Cambridge University Press, 1903)

St Augustine’s Abbey, Canterbury, ed. by B. C. Barker-Benfield, Corpus of British Medieval Library Catalogues, 13 (London: British Library, 2008)

Catalogi veteres librorum ecclesiae cathedralis Dunelm: Catalogues of the Library of Durham Cathedral, at Various Periods, from the Conquest to the Dissolution, Including Catalogues of the Library of the Abbey of Hulne, and of the MSS Preserved in the Library of Bishop Cosin, at Durham, ed. by Beriah Botfield, Surtees Society, 7 (London: Nichols, [1838])

Charles, B. D., and H. D. Emanuel, 'Notes on Old Libraries and Books', National Library of Wales Journal, 6 (1950), 353-72

The Riverside Chaucer, ed. by Larry D. Benson, 3rd edn (Oxford: Oxford University Press, 1987) 
A Collection of All the Wills, Now Known to be Extant, of the Kings and Queens of England, Princes and Princesses of Wales, and Every Branch of the Blood Royal, from the Reign of William the Conqueror, to that of Henry the Seventh Exclusive, ed. by John Nichols (London: Nichols, 1780)

The Collegiate Church of Ottery St Mary: Being the ordinacio et statuta ecclesie Sancte Marie de Otery, Exon. diocesis, A.D. 1338, 1339 (Cambridge: Cambridge University Press, 1917)

English Benedictine Libraries: The Shorter Catalogues, ed. by R. Sharpe and others, Corpus of British Medieval Library Catalogues, 4 (London: British Library, 1996)

Fœdera, conventiones, literæ, et cujuscunque generis acta publica, inter reges Anglice et alios, ed. by Thomas Rymer, Robert Sanderson and George Holmes, 3rd edn, 10 vols (The Hague: Neaulme, 1739-45)

Hemingby’s Register, ed. by Helena Mary Chew, Wiltshire Record Society, 18 (Devizes: Wiltshire Archaeological and Natural History Society, 1963)

Hibbard, Laura A., 'The Books of Simon de Burley, 1387’, Modern Language Notes, 30 (1915), pp. 169-71

The Ghost Stories of M. R. James, 2nd edn (London: Arnold, 1974)

The Libraries of the Cistercians, Gilbertines and Premonstratensians, ed. by David N. Bell, Corpus of British Medieval Library Catalogues, 3 (London: British Library, 1992)

Lincoln Diocese Documents 1450-1544, ed. by Andrew Clark, Early English Text Society, Original Series, 154 (London: Paul, Trench and Trübner, 1914)

The Register of Edmund Stafford (A.D. 1395-1419): An Index and Abstract of its Contents, ed. by F. C. Hingeston-Randolph (London: Bell, 1886)

The Register of Henry Chichele, Archbishop of Canterbury, 1414-1443, ed. by E. F. Jacob and H. C. Johnson, 4 vols, Canterbury and York Series, 45, 42, 46, 47 (Oxford, 1937-47)

The Register of John de Grandisson, Bishop of Exeter (A.D. 1327-1369), with Some Account of the Episcopate of James de Berkeley, ed. by F. C. Hingeston-Randolph, 3 vols (London: Bell, 1894-99)

The Register of Walter de Stapeldon, Bishop of Exeter (A.D. 1307-1326), ed. by F. C. Hingeston-Randolph (London: Bell, 1892)

Registrum Anglie de libris doctorum et auctorum veterum, ed. by Richard H. Rouse and Mary A. Rouse, Corpus of British Medieval Library Catalogues, 2 (London, 1991)

Syon Abbey, with the Libraries of the Carthusians, ed. by Vincent Gillespie (Syon) and A. I. Doyle (Carthusians), Corpus of British Medieval Library Catalogues, 9 (London: British Library, 2001) 
Testamenta Eboracensia, or, Wills Registered at York: Illustrative of the History, Manners, Language, Statistics, etc. of the Province of York, from the Year MCCC Downwards, ed. by James Raine and John William Clay, 6 vols, Surtees Society, 4, 30, 45, 53, 79, 106 (London: Nichols, 1836-1902)

Testamentary Records of the English and Welsh Episcopate, 1200-1413: Wills, Executors' Accounts and Inventories, and the Probate Process, ed. by C. M. Woolgar, Canterbury and York Series, 102 (York: Canterbury and York Society, 2011)

Thompson, A. Hamilton, 'The Will of Master William Doune, Archdeacon of Leicester', Archaeological Journal, 72 (1915), 233-84

John Wyclif's “De veritate Sacrae Scripturae”: Now First Edited from the Manuscripts with Critical and Historical Notes, ed. by Rudolf Buddensieg, 3 vols (London, 1905-07)

\section{Secondary Works}

[Anonymous], 'Report of the Committee Appointed by the Council of the Society of Antiquaries to Investigate the Circumstances Attending the Recent Discovery of a Body in St Stephen's Chapel, Westminster', Archaeologia, 34 (1852), 406-440

Bale, Anthony, 'Belligerent Literacy, Bookplates and Graffiti: Dorothy Helbarton's Book', in Book Destruction from the Medieval to the Contemporary, ed. by Gill Partington and Adam Smyth (Basingstoke: Palgrave, 2014), pp. 89-111

Baron, Naomi S., Words Onscreen: The Fate of Reading in a Digital World (Oxford: Oxford University Press, 2015)

Burgess, Clive, 'Late Medieval Wills and Pious Convention: Testamentary Evidence Reconsidered', in Profit, Piety and the Professions in Later Medieval England, ed. by M. Hicks (Gloucester: Sutton, 1990), pp. 14-33

Buringh, Eltjo, Medieval Manuscript Production in the Latin West: Explorations with a Global Database, Global Economic History, 6 (Leiden: Brill, 2011)

Burrow, J. A., Gestures and Looks in Medieval Narrative (Cambridge: Cambridge University Press, 2002)

Camille, Michael, 'The Book as Flesh and Fetish in Richard de Bury's Philobiblon', in The Book and the Body, ed. by Dolores Warwick Frese and Katherine O’Brien O’Keeffe, Ward-Phillips Lectures in English Language and Literature, 14 (Notre Dame, IN: University of Notre Dame Press, 1997), pp. 34-77

Carruthers, Mary, The Experience of Beauty in the Middle Ages (Oxford: Oxford University Press, 2013)

Cartlidge, Neil, 'Imagining X: A Lost Early Vernacular Miscellany', in Imagining the Book, ed. Stephen Kelly and John J. Thompson, Medieval Texts and Cultures of Northern Europe, 7 (Turnhout: Brepols, 2005), pp. 31-44 
Cavanaugh, Susan Hagen, 'A Study of Books Privately Owned in England, 1300-1450' (unpublished doctoral dissertation, University of Pennsylvania, 1985)

Cole, Gavin, and Thorlac Turville-Petre, 'Sir Thomas Chaworth's Books', in The Wollaton Medieval Manuscripts: Texts, Owners, Readers, ed. by Ralph Hanna and Thorlac Turville-Petre, Manuscript Culture in the British Isles, 3 (Woodbridge: York Medieval Press, 2010), pp. 20-29

D’Avray, D. L., Medieval Marriage Sermons: Mass Communication in a Culture without Print (Oxford: Oxford University Press, 2001)

Da Rold, Orietta, 'Materials', in The Production of Books in England 1350-1500, ed. by Alexandra Gillespie and Daniel Wakelin, Cambridge Studies in Palaeography and Codicology, 14 (Cambridge: Cambridge University Press, 2011), pp. 12-33

Doyle, A. I., 'A Letter Written by Thomas Betson, Brother of Syon Abbey', in The Medieval Book and a Modern Collector: Essays in Honour of Toshiyuki Takamiya, ed. by Takami Matsuda, Richard A. Linenthal and John Scahill (Cambridge: Brewer, 2004), pp. 255-67

Edwards, A. S. G., 'M. R. James, “Canon Alberic’s Scrap-Book”, and “Dennistoun”, Notes and Queries, 58 (2011), 104-5

Emden, A. B., A Biographical Register of the University of Cambridge to 1500 (Cambridge: Cambridge University Press, 1963)

Gasnault, Pierre, 'Observations paléographiques et codicologiques tirées de l’inventaire de la Librairie pontificale de 1369’, Scriptorium, 34 (1980), 269-75

Gillespie, Alexandra, 'The History of the Book', New Medieval Literatures, 9 (2007), 245-77

— - 'Bookbinding', in The Production of Books in England 1350-1500, ed. by Alexandra Gillespie and Daniel Wakelin, Cambridge Studies in Palaeography and Codicology, 14 (Cambridge: Cambridge University Press, 2011), pp. 150-72

Goldberg, P. J. P., 'The Fashioning of Bourgeois Domesticity in Later Medieval England: A Material Culture Perspective', in Medieval Domesticity: Home, Housing and Household in Medieval England, ed. by Maryanne Kowaleski and P. J. P. Goldberg (Cambridge: Cambridge University Press, 2008), pp. 124-44

Gumbert, J. P., 'Fifty Years of Codicology’, Archiv für Diplomatik, 50 (2004), 505-26

Hamel, Christopher de, Syon Abbey: The Library of the Bridgettine Nuns and their Peregrinations after the Reformation (Otley: Roxburghe Club, 1991)

Hanna, Ralph, 'Problems of "Best Text” Editing and the Hengwrt Manuscript of The Canterbury Tales', in Manuscripts and Texts: Editorial Problems in Later Middle English Literature, ed. by Derek Pearsall (Cambridge: Brewer, 1987), pp. 87-94 
James, M. R., A Descriptive Catalogue of the Manuscripts in the Library of Jesus College, Cambridge (London: Clay, 1895),

Ker, N. R., Books, Collectors and Libraries: Studies in the Medieval Heritage, History Series, 36, Literature Series, 2 (London: Hambledon 1985)

—-, Pastedowns in Oxford Bindings, with a Survey of Oxford Binding c. 1515-1620, Oxford Bibliographical Society, New Series, 5 (Oxford: Broome, 1954)

L'Engle, Susan, and Robert Gibbs, Illuminating the Law: Legal Manuscripts in Cambridge Collections (London: Harvey Miller, 2001)

Lerer, Seth, 'Bibliographical Theory and the Textuality of the Codex: Toward a History of the Premodern Book', in The Medieval Manuscript Book: Cultural Approaches, ed. by Michael Johnston and Michael Van Dussen (Cambridge, 2015), pp. 17-33

Levy, Ian Christopher, 'The Place of Holy Scripture in John Wyclif’s Theology', in The Wycliffite Bible: Origin, History and Interpretation, ed. by Elizabeth Solopova, Medieval and Renaissance Authors and Texts, 16 (Leiden: Brill, 2017), pp. 27-48

Meale, Carol M., ““....alle the bokes that I haue of latyn, englisch and frensch”: Laywomen and their Books in Late Medieval England', in Women and Literature in Britain, 1150-1500, ed. by Carol M. Meale (Cambridge: Cambridge University Press, 1993), pp. 128-58

Minnis, A. J., Medieval Theory of Authorship: Scholastic Literary Attitudes in the Later Middle Ages, 2nd edn (Aldershot, 1988)

Moretti, Franco, 'The Slaughterhouse of Literature', Modern Language Quarterly, 61 (2000), 207-227

—_ 'Style, Inc.: Reflections on Seven Thousand Titles (British Novels, 1740-1850)', Critical Inquiry, 36 (2009), 134-158

Nichols, Stephen G., 'Philology and its Discontents', in The Future of the Middle Ages: Medieval Literature in the 1990s, ed. by William D. Paden (Gainesville, FL: University Press of Florida, 1994), pp. 113-41

Novacich, Sarah Elliott, Shaping the Archive in Late Medieval England: History, Poetry, and Performance (Cambridge: Cambridge University Press, 2017)

Oliver, George, Lives of the Bishops of Exeter, and a History of the Cathedral, with an Illustrative Appendix (Exeter: Roberts, 1861)

Rosenthal, Joel T., 'Clerical Book Bequests: A Vade mecum, But Whence and Whither?', in The Church and Learning in Later Medieval Society: Essays in Honour of R. B. Dobson, ed. by Caroline M. Barron and Jenny Stratford, Harlaxton Medieval Studies 11 (Donington, 2002), pp. 327-43 
Rouse, Richard, and Mary Rouse, 'Will Power: Manuscripts in Medieval Testaments', in Manuscripta Illuminata: Approaches to Understanding Medieval and Renaissance Manuscripts, ed. by Colum Hourihane (Princeton: Penn State, 2014), pp. 207-220

Rundle, David, 'Habits of Manuscript-Collecting: The Dispersals of the Library of Humfrey, Duke of Gloucester', in Lost Libraries: The Destruction of Great Book Collections Since Antiquity, ed. by James Raven (Basingstoke: Palgrave, 2004), pp. 106-124

Ruzzier, Chiara, 'The Miniaturization of Bible Manuscripts in the Thirteenth Century: A Comparative Study', in Form and Function in the Late Medieval Bible, ed. by Eyal Poleg and Laura Light, Library of the Written Word: Manuscript World, 4 (Leiden: Brill, 2013), pp. 105-125

Sargent, Michael, 'What Do the Numbers Mean? A Textual Critic’s Observations on Some Patterns of Middle English Manuscript Transmission', in Design and Distribution of Late Medieval Manuscripts in England, ed. Margaret Connolly and Linne Mooney (Woodbridge: York Medieval Press, 2008), pp. 205-44

Sawyer, Daniel, 'Navigation by Tab and Thread: Place-Markers and Readers' Movements in Books', in Spaces for Reading in Later Medieval England, ed. Mary C. Flannery and Carrie Griffin (London: Palgrave, 2016), pp. 99-114

Scattergood, John, Manuscripts and Ghosts (Dublin: Four Courts, 2006)

Sharpe, Richard, 'Library Catalogues and Indexes', in The Cambridge History of the Book in Britain, ed. by John Barnard, David McKitterick and I. R. Willison, 6 vols (Cambridge: Cambridge University Press, 1999-2010), vi (2008), pp. 197-218

Smith, D. Vance, 'The Shadow of the Book: Piers Plowman, The Ilchester Prologue, and Inhumane Revision', in Yee? Baw for Bokes: Essays on Manuscripts and Poetics in Honor of Hoyt N. Duggan, ed. by Michael Calabrese and Stephen H. A. Shepherd (Los Angeles: Marymount Institute, 2013), pp. 203-18

Spedding, Alison J., 'Hoc est testamentum: The Structure and Development of Introductory Clauses in Latin Testamentary Writing’, Viator, 45 (2014), 281-309

Szirmai, J. A., The Archaeology of Medieval Bookbinding (Aldershot: Ashgate, 1999)

Treharne, Elaine, 'The Broken Book II: From a Book of Hours to a Book of Bits', 23 November 2013, <https:/historyoftexttechnologies.blogspot.co.uk/2013/11/thebroken-book-ii-from-book-of-hours.html> [accessed 10 November 2017]

Wakelin, Daniel, ‘William Worcester Writes a History of His Reading', New Medieval Literatures, 7 (2005), 53-71

Wieck, Roger S., 'Folia Fugitiva: The Pursuit of the Illuminated Manuscript Leaf', Journal of the Walters Art Gallery, 54 (1996), 233-54

Wilson, R. M., The Lost Literature of Medieval England, 2nd edn (London: Methuen, 1970) 